\title{
First palaeoseismological results from Greece
}

\author{
Spyros Pavlides (*) \\ Aristotle University of Thessaloniki, Department of Geology, Thessaloniki, Greece
}

\begin{abstract}
This is a brief account of our approach to trends in palaeoseismological research that are currently emerging in Greece, with the application of modern investigative methods practised world-wide in active tectonic zones. These techniques include fault stratigraphy in trenches, and dating recent fault reactivations in order to understand and distinguish palaeoseismic events along specific segments of active faults, named Gerakarou (Mygdonia Basin, Thessaloniki area), Palaeochori Fault (Kozani-Grevena, Western Macedonia), Souli (Petousi, Epirus), and Volos-Larissa (Thessaly plain). Four palaeoearthquakes were investigated on the Gerakarou fault segment, with a uniform slip rate and return period around 7000 years. In Western Macedonia «aseismic areas» the Servia-Palaeochori recently activated fault shows a $\sim 3500$ year quiescence. Three coseismic events on the Souli Fault pre- and post-date to 26000 year deposits.
\end{abstract}

Key words palaeoseismology - Holocene palaeosoils - active faults - seismotectonics of Greece

\section{Introduction}

Palaeoseismology is a new and exciting dynamic field of geoscience research, especially neotectonics - active tectonics. Although the current bibliography uses many terms to describe recent movements and deformation of the earth's crust, palaeoseismology is defined by its specific, mainly geological methods, as well as its aim to investigate pre-instrumental earthquakes, especially those recorded in the near geological past (for the definition of the subject see Wallace 1981, 1987; Crone and Omdahl, 1987; Yeats and Schwartz, 1990). In tectonically active areas, the estimation of the recurrence of moderate-large earthquakes and their location and magnitude are highly valu-

(*) e-mail: Pavlides@ Olymp.ccf.auth.gr able, while the study of neotectonic and active faults (neotectonic research) and the seismogenic structures with detailed field measurements (palaeoseismological research) is of crucial importance. Hence the potential of palaeoseismology is only just being recognised especially in European and Mediterranean countries.

Palaeoseismological studies are not new, with ideas on the earthquake geology, such as «fossil earthquakes» and the importance of palaeoseismic events having been recognised many years ago. However, there has been an explosion of palaeoseismic research and activities since the seventies (e.g., Sieh, 1981; Crone and Omdahl, 1987; Vittori et al., 1991; Prentice et al., 1994). New methods and techniques have been developed and important results have arisen from seismically active countries such as: U.S.A.; Russia; Japan; China; Italy etc. (e.g. Meghraoui et al., 1988; Pantosti et al., 1993; Nikonov, 1995), as well as from less seismically active areas such as Scotland, Fennoscandinavia and many others (e.g., Ringrose, 1989; Lagerback, 1990; Mörner and 
Troften, 1993). Although Greece is a seismically very active region, neotectonic studies encompass all deformations that post-date the last Alpide deformation and have focused especially on the geometry, architecture and kinematics of active faults.

More than 100 instrumentally recorded earthquakes $M>6.0$ in the Aegean area occurred in the present century and more than 200 large historical seismic events are known in Greece. These earthquakes have originated from known active faults, although only few of them have been associated to specific seismogenic faults or show surface fault traces.

Although interesting work, new data and results have appeared during the last 20 years or so, only recently has there been an increasing interest in defining specific seismic events with the use of geological methodology and trenching excavation in particular. A lot of work has also been done on the historical seismicity of the broader area (e.g., Ambraseys, 1975; Papazachos and Papazachou, 1989; Guidoboni, 1989; Ambraseys and Finkel, 1995), while important but scattered information exists in many archaeological publications, non systematic and sometimes not well documented.

Some attempts to correlate systematically archaeological and geological evidence for large historical earthquakes in Greece have recently been carried out positively: e.g., Stiros (1988); Guidoboni (1989); Armijo et al. (1991) for the destructive Sparta (SE Peloponnesus) 464 B.C. earthquake, one of the oldest known historical seismic events in Greece; Mouyaris et al. (1992) for the Helice 373 B.C. large earthquake. Papanastassiou et al. (1993), verified events (e.g., 1250 A.D., 1190 A.D. Peloponnesus) suggested by archaeological evidence. Additional results on the correlation of archaeological and sea-level changes have been overviewed by Stiros and Pirazzoli (1995).

This paper presents the contribution of tecto-stratigraphic studies from some specific active faults in northern Greece to the recognition of individual earthquakes of the recent geological past. These are preliminary results (Pavlides et al., 1992; Cheng et al., 1994; Chatzipetros and Pavlides, 1994; Pavlides,
1994), which open this relatively new subject in Greece, but raise new questions on the recognition and dating of individual coseismic events or seismic episodes (more than one moderate earthquake) in the late Pleistocene and Holocene sediments and their significance.

\section{Distinguishing and dating seismic events: the stratigraphic approach}

\subsection{Thessaloniki active faults}

Mygdonia depression, which is the Thessaloniki $1902(M=6.6)$ and $1978(M=6.5)$ seismogenic area, is located about $20 \mathrm{~km} \mathrm{NE}$ of the city of Thessaloniki (Central Macedonia, North Aegean broader region, Greece) (figs. 1 and 2). It is a relatively small and narrow Neogene-Quaternary basin, part of a longer seismically active belt trending NW-SE along the socalled Serbomacedonian geological zone, an old crystalline massif affected by alpide deformation, but also cut by numerous neotectonic faults (NW-SE, E-W and NE-SW trending). For the neotectonics and seismotectonics of the region see Pavlides and Kilias (1987), Voidomatis et al. (1990) and Pavlides and Soulakellis (1990).

As a first step towards understanding the past (mainly late Quaternary) behaviour of earthquake-producing faults, a quantitative investigation of slope variations and ages of fault scarps was attempted on some active fault scarps of the Mygdonia basin (Chatzipetros and Pavlides, 1994).

Trenching excavation at a specific fault segment, named Gerakarou segment, which is a branch of the Southern Mygdonia marginal fault and which activated during the 1978 $\left(M_{s}=6.5\right)$ shock, was undertaken (figs. 2 and $3)$. At first, an excavation was carried out across a 2-4 $\mathrm{m}$ high scarp about $25 \mathrm{~m}$ south of the 1978 fault traces within a farming area, but undeformed Holocene sediments showed that it was not a fault scarp (fig. 3). The possible explanations are that it is either an erosional scarp or an eroded tectonic scarp reduced by farming activity. 


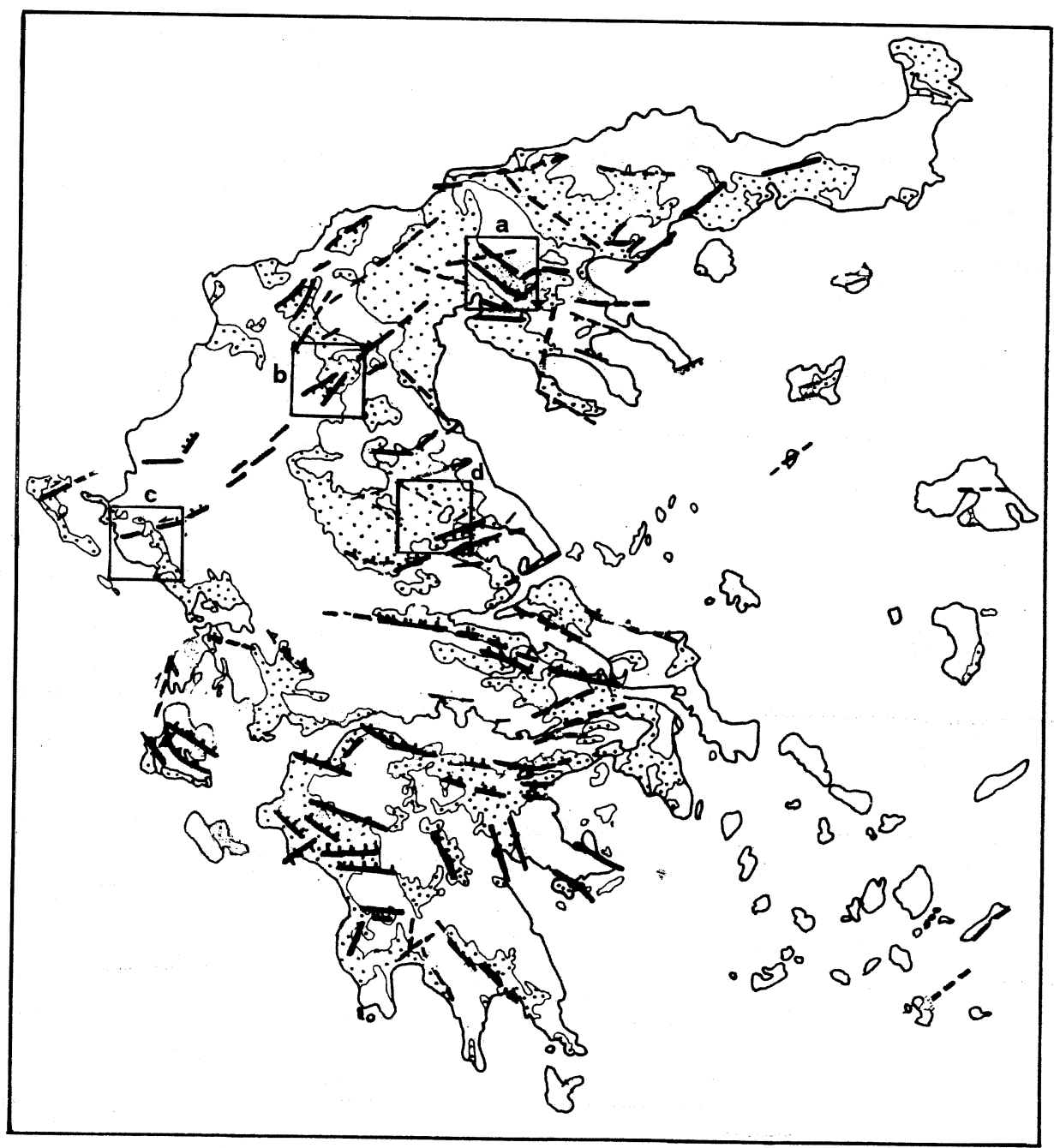

Fig. 1. A sketch map of active faults of continental Greece, also showing the study areas in boxes, named: a) Mygdonia Basin (Thessaloniki area, Central Macedonia); b) Kozani-Grevena (Western Macedonia district); c) Souli (or Petousi) Fault (Epirus, North-Western Greece); d) Larissa sub-basin (Thessaly plain, Central Greece). Faults are shown by heavy lines, while known normal structures are shown with ticks on the downthrown side. Neogene-Quaternary basins are also shown dotted.

The main trench is located across the southernmost fracture produced by the last great seismic event. It exposes an upper fracture zone consisting of at least eight fractures and a lower fault strand that is incorporated by fractures below the depth of $2 \mathrm{~m}$ (figs. 3 and 4). The trench exposes lacustrine deposits buried by a fan sequence including three or four palaeosoils clear erosional surfaces (fig. 4). Furthermore, surfaces are developed on top of units (2) and (3), which was probably caused by the higher levels of the Volvi palaeolake. Colluvial wedge deposits and especially the nature and origin of palaeosoils, their thicken- 


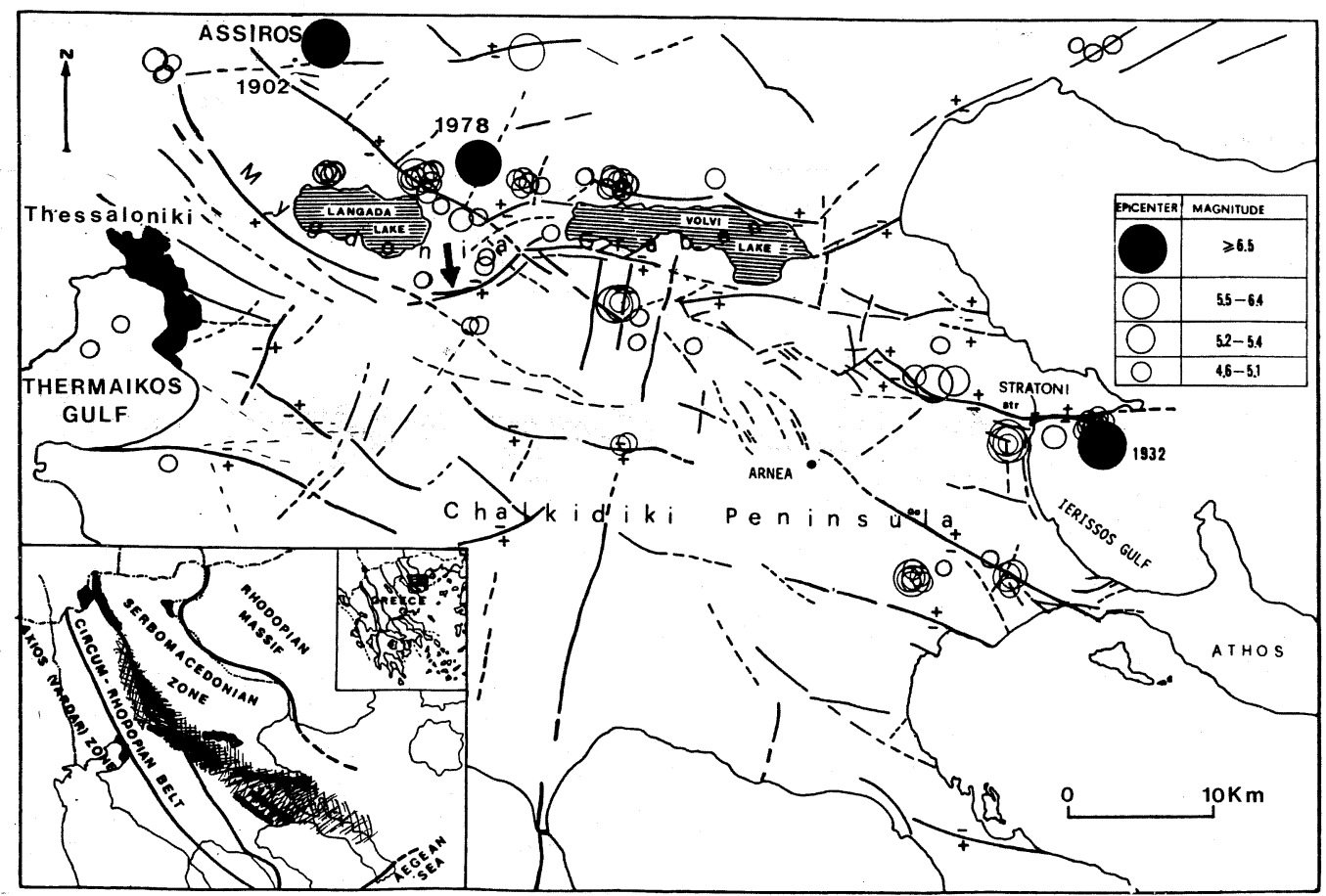

Fig. 2. Tectonic sketch map of the Chalkidiki and Mygdonia (Langada and Volvi lakes) region (from Pavlides and Kilias, 1987; Voidomatis et al., 1990). Neotectonic faults are shown as lines with positive $(+)$ and negative $(-)$ signs indicating the relative fault motions (normal component) and circles representing epicenters of earthquakes $M \geq 5.0$. Arrow shows the Gerakarou Fault segment. Lower left shows the broader Central Macedonia region with the geotectonic zones. The shaded areas define the most seismic belt within the Serbomacedonian zone.

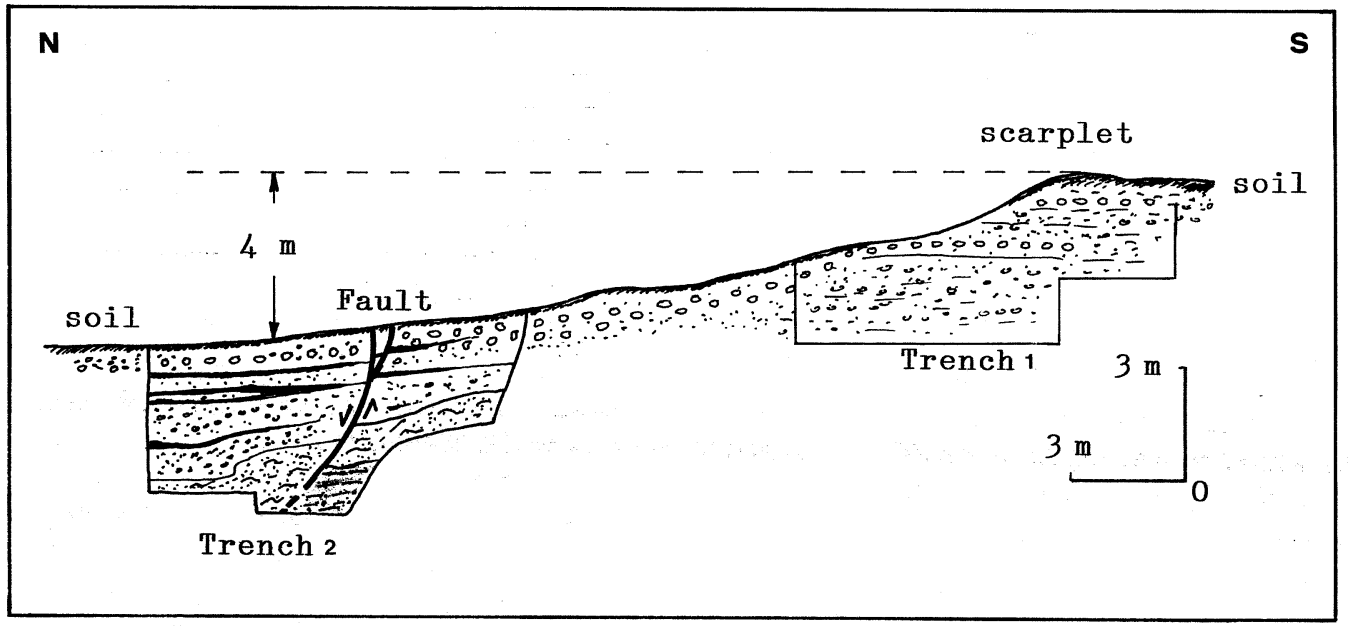

Fig. 3. Topographic profile of the area where trench excavation was carried out across a 2 to $4 \mathrm{~m}$ high scarplet (trench 1, where undeformed Holocene sediments were exposed) and across a 1978 earthquake rupture (trench 2) (see also fig. 4). 


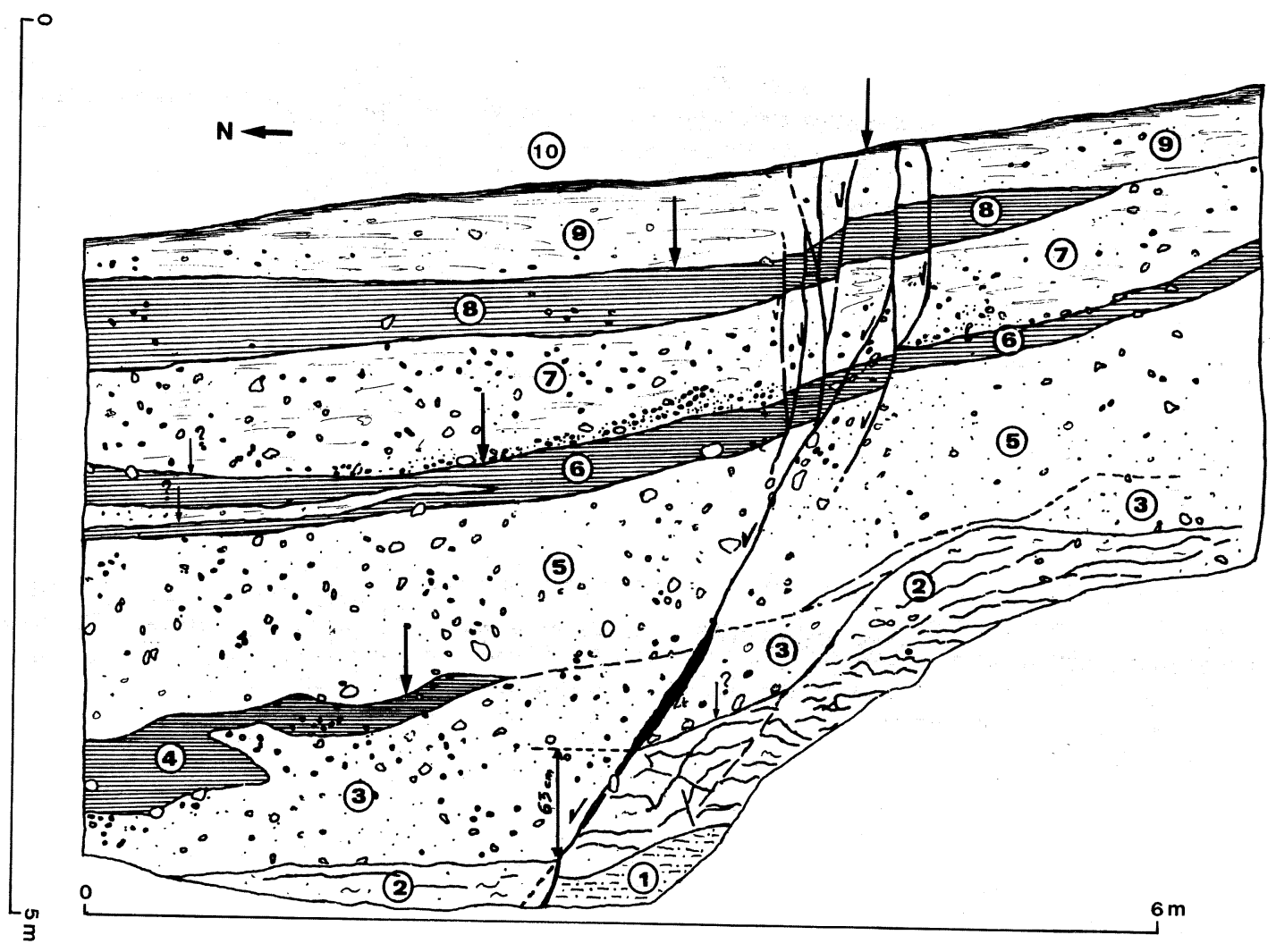

Fig. 4. Simplified log of trench 2 (east well) across the Gerakarou Fault segment on the southern margin of the Mygdonia depression. The trench shows the following lithologic units: $1=$ clay silt; $2=$ sand with deposition structures known as «seismites», which could be interpreted as related to earthquake shacking; $3=$ clay rubble and fine gravel (Colluvium); $4=$ palaeosoil; $5=$ clay rubble; $6=$ dubbed layered palaeosoil; $7=$ clay rubble; $8=$ palaeosoil; 9 = fine gravel and clay rubble; $10=$ the recent soil. Thermoluminescence dating on the palaeosoils suggests a uniform earthquake cycle recurrence interval of 7000 years. (Palaeosoil 4 is $21700 \pm 1800$ years; 6 is $14000 \pm 1100$ years; 8 is $7200 \pm 600$ years).

ing along with the observed fault displacements, are the main basis to reconstruct the past seismic activity. Palaeosoils represent periods of non-deposition during relative tectonic stability and favourable climatic conditions. From the trenches it appears that there is a good correspondence between colluvial sedimentation on the lake erosional scarp and faulting on the basin margin fault zone, but the phenomenon would probably imply an internal genetic relationship between episodic climatic changes since the late Pleistocene-Holocene, resulting in Colluvial sedimentation on the scarp.

The deposits exposed in the trench show different amounts of displacement: the older lacustrine deposits, liquefied sand (unit 2) and possibly the clay silt (1) are displaced by a total of $63-68 \mathrm{~cm}$, while the second soil layer (unit 4) is vertically offset $20 \mathrm{~cm}$, and the uppermost soil (unit 8) layer is displaced by $\sim 10 \mathrm{~cm}$. Thermoluminescence dating of the materials from the three layers has shown: $2.17 \pm 0.18 \times 10^{4}$ B.P., $1.40 \pm 0.11 \times 10^{4}$ B.P., 
$0.72 \pm 0.06 \times 10^{4}$ B.P. Tla, from the deepest to the uppermost layer respectively. A sample from the second palaeosoil layer was dated by $\mathrm{C}^{14}$ as $2350 \pm 80$ B.P., but because there is a great influence of surface carbon in the deepest layers of this agricultural area (carbon circulation in the uppermost soft deposits), this age is not considered representative of the true age of this layer.

The palaeoseismicity at the Gerakarou segment is characterised by the similarity in displacement per event $(10$ to $16 \mathrm{~cm})$ and although the dated soils show the lower and upper time limits of the possibly coseismic events, the recurrence interval (about 7000 years) seems uniform with the same magnitude episodically occurring earthquakes (or episodes) within the segment. An exception could be the division into two branches of the second soil layer (unit 4), which may reflect two seismic events during a short period of time or just a climatic change. Using this single parameter, the slip-rate of the segment can be considered of the order of 0.03 to $0.06 \mathrm{~mm} /$ $\mathrm{yr}$, an extremely low rate for a seismic fault; that is, an average to moderate activity fault. Slip-rate measurements have large uncertainties, while multiple techniques are necessary.

The consistence of the surface displacement of both palaeoseismic events at Gerakarou segment and the 1978 earthquake show that the maximum magnitude estimated from palaoseismic data is comparable to that of the 1978 earthquake, $M_{s}=6.5$ and $1902 M_{s}=6.6$. Both prehistoric (geologically determined) and historic seismic records similarly reflect the basic strength level in producing earthquakes for the Southern Mygdonia Basin. The Gerakarou Fault segment tends to generate essentially the same size earthquakes at or near the maximum magnitude that can be produced by the geometry, mechanical properties, and state of stress of that fault or segment, that is a «characteristic earthquake» (see Schwartz and Coppersmith, 1984). In fact, it is not known if such fault behaviour of this specific segment, would reflect the long-term conduct at the whole Southern Mygdonia Fault. Future work is needed to show distribution regularity of cumulative slip, significant slip rates, and displacement per event along the total active fault zone.

\subsection{Kozani-Grevena (Western Macedonia district; Northern Greece)}

Some potentially active faults may remain dormant and aseismic for long periods of geologic time and, at a certain time may generate destructive earthquakes with little or no precursory seismicity. A typical example is the recently activated (13 May $\left.1995 ; M_{s}=6.6\right)$ fault of Servia-Palaeochori (Kozani-Grevena area), (figs. 1 and 5).

This fault zone is located in Western Macedonia, which is considered an «aseismic» or «very low seismicity» area, according to instrumental or historical seismicity alone (see Pavlides at al., 1995). However, the area is dominated by great neotectonic faults, activated during the Quaternary, and in some cases particularly active during the Holocene. This is of crucial importance to look for the recent seismic history of these faults. The study is still in progress, but preliminary results show an interesting seismic history for the Palaeochori segment. According to $\mathrm{C}^{14}$ dating and fault scarp tecto-stratigraphic interpretation, it remained quiet for more than 3500 years at least. Moreover two or three previous palaeoevents have been recognised in a «short period of time». That is, a clustering of events on the fault (seismic episode or seismic cycle) which consists of one or more moderate to large magnitude earthquakes $(M>5.5)$ separated by a quiescent interval.

\subsection{Souli (or Petoussi) Fault}

Additional palaeoseismic data arise from a well known (IFP-IGRS, 1966) alpidic strikeslip fault, Souli or Petoussi Fault in Epirus, NW Greece (figs. 1 and 6). This E-W trending left-lateral fault is a relatively old structure which affects Lias-Eocene carbonate and siliceous rocks and Oligocene-Burdigalian flysch of the Ionian Zone (the western geological zone of the Greek orogene). Clear geomorphic features, such as young debris, sag-ponds, terraces etc., have been recognised along this fault as evidence of a neotectonic structure. An interesting site on the fault is an outcrop of 


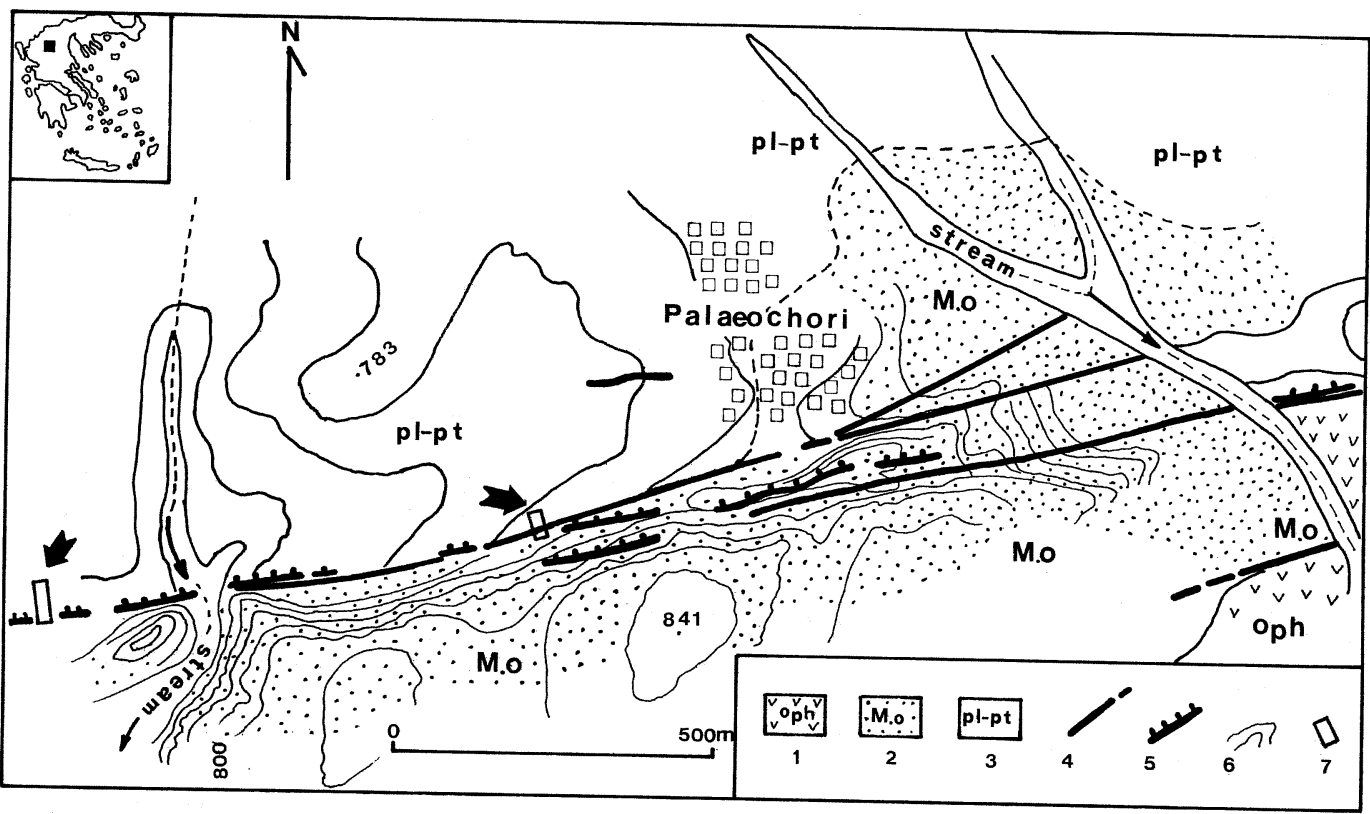

Fig. 5. Faults activated during the last earthquake $\left(1995 ; M_{s}=6.6\right.$ Western Macedonia earthquake; Pavlides et al., 1995) in the vicinity of the Palaeochori village. $1=$ ophiolites; $2=$ molassic sediments; $3=$ Plio-Pleistocene deposits; $4=$ neotectonic fault; $5=$ seismic fault traces; $6=$ elevation contours in meters; $7=$ palaeoearthquakes even though there may not be any record of like this one, have the potential of producing large earthquakes even though there may not be any record of historical and instrumental earthquakes.

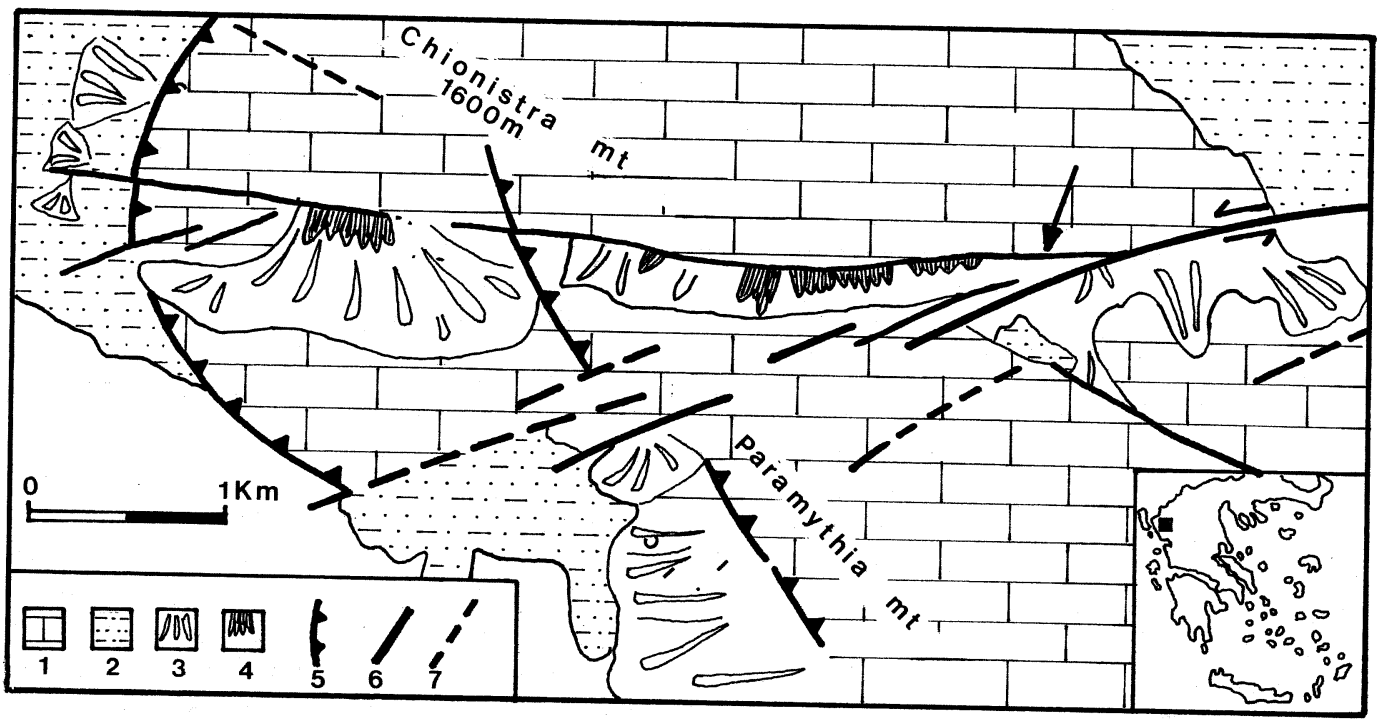

Fig. 6. Western portion of the Souli (or Petoussi) Fault (Epirus, North-Western Greece). $1=$ Lias-Eocene limestones; 2 = Upper Eocene-Lower Miocene Ionian flysh; $3=$ Quaternary scree; $4=$ very recent scree; $5=$ thrust; 6 fault; 7 = probable fault. The arrow shows the studied palaeoseismological outcrop (see fig. 7 ). 


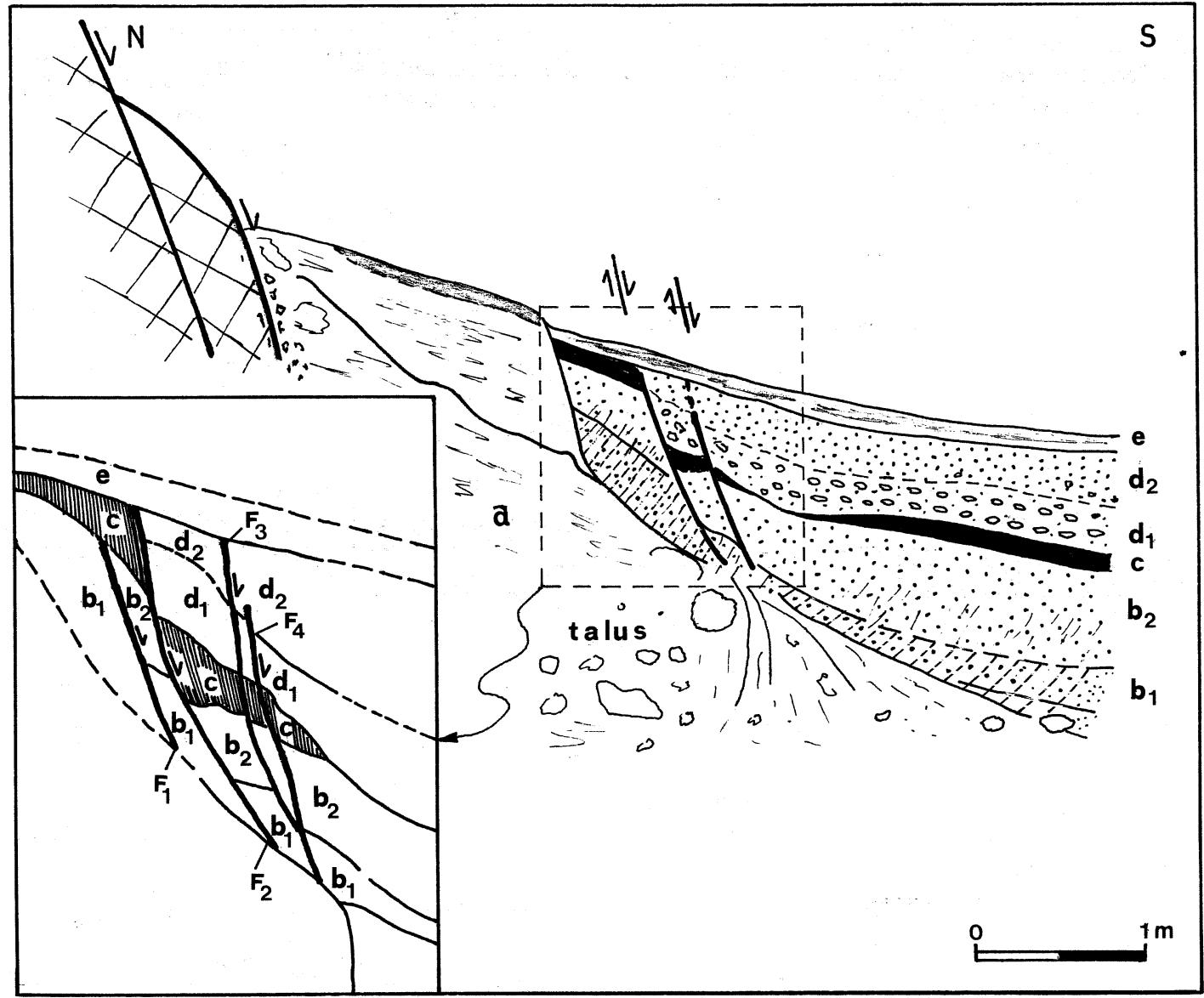

Fig. 7. Sketch of the natural trench exposure across the Souli Fault (see site in fig. 6). The lithologic units are: $a=$ talus; $b_{1}$ and $b_{2}=$ lacustine clay sand; $c=$ carbon rich lignite type layer; $d_{1}$ and $d_{2}=$ unconsolidated gravel of colluvium type; $\mathrm{e}=$ recent soil. Detail of the secondary fault zone (tectonic stratigraphy) is shown in the box in the bottom left corner. Event associated with $\mathrm{F}_{1}$ faulting affecting b layers predates deposits $\mathrm{c}$, dated $\mathrm{C}^{14} 20000$ to 26000 years. Event(s) associated $\mathrm{F}_{2}, \mathrm{~F}_{3}$ and $\mathrm{F}_{4}$ faulting post-dates layer $\mathrm{c}$ and $\mathrm{d}$.

sag-pond type recent sediments, as shown in fig. 6 (see also Boccaletti et al., 1994), which can be considered a «natural palaeoseimic outcrop». In this outcrop a rich lignite type was layer dated 20000 to 26000 B.P. years by $C^{14}$. Stratigraphy and the observed structures of the section suggest evidence for several palaeoseismic events. The fault surface (fault plane or scarp) and the corresponding debris ( $\mathrm{a}$ in fig. 7) are related to older episodes associated with lagoon formation and sedimentation. The palaeoseismic interest comes from the small secondary faults, which affect the late quaternary lagoon deposits, and thus are related to younger events (see detail of fig. 7). The first palaeoevent is associated with $\mathrm{F}_{1}$ faulting and pre-dates layer c (lignite 26000 years B.P.), while the second event is connected with the $\mathrm{F}_{2}$ faulting post-dating layer c. A possible third event could be associated with $\mathrm{F}_{3}$ and $\mathrm{F}_{4}$ faults. 
The maximum observed displacement is $20 \mathrm{~cm}$ that could correspond to a moderate size earthquake. It is important to notice that this is the first time that this Alpide fault has been recognised as active (Pavlides et al., 1992; Boccaletti et al., 1994), following the definitions of various public agencies based on the frequency of the occurrence of specific faulting events (e.g., 10000 years or 35000 years or 500000 years).

\subsection{Tecto-stratigraphic preliminary study in the Thessaly plain}

Neotectonic studies in Thessaly (fig.1) have indicated a number of active faults, showing clear young geomorphic features, directly or indirectly associated with strong and weak earthquakes (Caputo and Pavlides, 1993). Trenching excavation techniques, not strictly for palaeoseismic research but for detecting tectonic origin indicators, have been applied on two of these faults affecting Eastern Thessaly plain recent alluvial deposits and showing creeping phenomena. One of these trenches is shown in fig. 8. This is from a fault located between the marginal Neogene and basement formation of the Larissa Basin (Thessaly, Central Greece) showing periodically open cracks during the last two years (1993-1995). The outcrop shows an older, but similar to the present, sphen of 2000 years and displaced layers of 7000 , while the observed displacement is interpreted as a tectonic effect (aseismic creep) rather than aquifer compaction (water-level decline) (Zouros et al., 1994).

\section{Discussion and conclusions}

This paper presents the recent attempts to define palaeoseismic events in the geological record on the Greek mainland. The first attempt was based on the application of quantitative morphotectonic analyses on some active

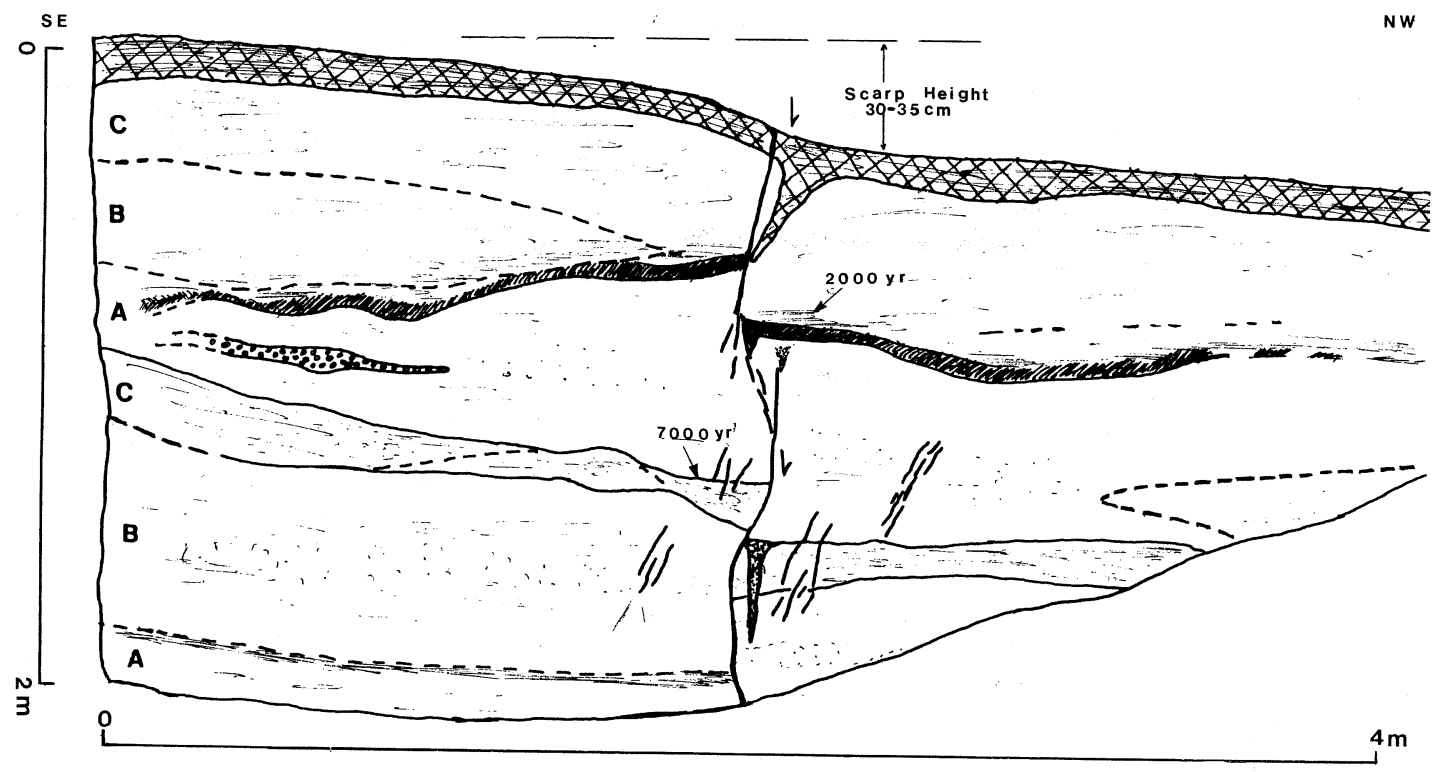

Fig. 8. Sketch of a trench in the Southern Larissa Basin (Thessaly) in Holocene sediments across a secondary active fault (Risomilos village). The trench shows faulting displacing soft sediments dated 2000 to 7000 years (Thermoluminescence dating). These structures are similar to that created during the recent «aseismic» creep-
ing events. 
fault scarps, whereas the second was based on identifying and dating palaeoseismic events along some specific sites of active faults, using trenching techniques; that is the tecto-stratigraphic approach in palaeoseismology in order to learn as much as possible about the seismic history of the faults. The preliminary results show that:

a) At least three to four palaeoearthquakes have been recognised on the Gerakarou segment (Thessaloniki area, Northern Greece) by trenching and dating colluvium and palaeosoil deposits. Taking into account the dating and measurement uncertainties this fault segment shows a slip rate $\sim 0.03$ to $0.06 \mathrm{~mm} / \mathrm{yr}$, which seems to be equally spaced in time. Comparing the results of geomorphology and fault scarp degradation, the seismic history of the region (historic and instrumental data), and the displacement produced by palaeoearthquakes of 10 to $16 \mathrm{~cm}$ per event, suggest that the common magnitude for the earthquakes produced by this fault is 6.5 , similar to that of the 1978 event.

The palaeoseismic analysis for recognising individual palaeoearthquakes in the Mygdonia basin, as well as in the other sites, suggests that we must involve trenching in multiple sites along the same fault segment, as well as along the same fault zone, especially at scarps, where scarp height changes dramatically. A second crucial point is the reliability of correct dating. In the specific trench of Gerakarou (Mygdonia Basin; Thessaloniki) serious problems emerged from the contradicting results of $\mathrm{C}^{14}$ dating versus thermoluminescence, as well as from dating the whole palaeosoil. The number of events should be clearly determined, whether the palaeosoils yield the number of faulting events or not. Special attention must be given to nontectonic deposits; wedge soils and stratigraphic facies of tectonic and nontectonic origin complicate the results.

b) In contrast to the Gerakarou Fault segment with the uniform slip-rate, the Palaeochori (Western Macedonia) Fault segment shows long periods of quiescent and non uniform seismic episodes. c) Three, or possibly four, distinct coseismic events have been recognised on a segment of the Souli Fault (Epirus), pre- and post-dating wedge layers of 20000 to 26000 years $\left(\mathrm{C}^{14}\right)$ deposits, but the slip rate of the segment has not been calculated.

d) The trenching excavation techniques have been also used in Thessaly (NorthernCentral Greece) to detect tectonic origin indicators in Holocene sediments along creeping faults.

To establish the limits of our resolution to clarify the reliability of the palaeoseismological data and results, seismologists and engineers who are going to use palaeoseismological results must clearly know the erroneous ages of the events geologically determined.

Preliminary or limited data from a fault lead to one interpretation, while considering additional trenching data from the same fault may lead to a second interpretation different from the first one. Therefore it is likely that future work on the above referred faults will make this study much more complete. The results of this study atso show the potential of palaeoseismology in Greece. However, the uncertainties related to dating and difficulty in detecting small displacements (of the order 8 to $20 \mathrm{~cm}$ ), that seem to be characteristic of the "Greek earthquakes» $\left(M_{s}=6.0\right.$ to 7.0$)$, stress the need for a systematic palaeoseismology study.

\section{Acknowledgements}

Thanks are due to my Chinese colleagues at the Institute of Geology (SSB, Beijing) Fang Z. and Cheng S., as well as my post-graduate student A. Chatzipetros, for their help in the field and in interpreting the data. Special thanks are also due to Iain Stewart, D. Pantosti, M. Meghraoui and one anonymous reviewer for careful reading of the manuscript and for the useful corrections. Finally I must acknowledge the contribution and help of D. Mountrakis, M. Boccaletti, N. Zouros, R. Caputo, K. Peftitselis and E. Karakala. 


\section{REFERENCES}

AMBRASEYS, N.N. (1975): Studies in historical seismicity and tectonics, in Geodynamics of Today, The Royal Society London, 7-16.

AMbraseys, N. and C. FINKEL (1995): The seismicity of Turkey, Eren Publ., Istanbul.

Armijo, R., H. LyON-CAEN and D. PAPANAStassiou (1991): A possible normal-fault rupture for the 464 B.C. Sparta earthquake, Nature, 351, 137-139.

Boccaletti, M., R. CAPUTO, D. Mountrakis, S. PAVLIDES and N. Zouros (1994): Paleoseismicity of the Souli fault, Epirus, Western Greece, in Proceedings Workshop on Paleoseismology (Schwartz and Yeats Eds., CA, U.S.A), 21-23.

CAPuto, R. and S. PAVlides (1993): Late Cainozoic geodynamic evolution of Thessaly and surrounding (Central-Northern Greece), Tectonophysics, 223, 339-362.

Chatzipetros, A. and S. PAVliDes (1994): Late Quaternary fault scarps and paleoseismology of the active basin of Mygdonia, Thessaloniki seismogenic area, Northern Greece, in Proceedings Workshop on Paleoseismology (Schwartz and Yeats Eds., CA. U.S.A), 35-37.

Cheng, S., Z. Fang, S. Pavlides and A. Chatzipetros (1994): Preliminary study of Paleoseismicity of the Southern Langada-Volvi basin margin fault zone, Thessaloniki Greece, in 7th Congr. Geol. Soc. Gr. Thess., May 1994, abstract 46-47.

CRONE, A.J. and E.M. OMDAHL (Editors) (1987): Directions in paleoseismology, U.S.G.S., in Proceedings of Conference XXXIX, Open-file Report 87-673.

Guidoboni, E. (Editor) (1989): I Terremoti Prima del Mille in Italia e nell'Area Mediterranea, Storia Archeologia Sismologia (Istituto Nazionale di Geofisica), Bologna, pp. 765.

IFP-IGRS (1966): Edude Geologique de l'Epire (Ed. Technip), pp. 306.

LAGERBACK, R. (1990): Late Quaternary faulting and paleoseismicity in Northern Fennoscandia, with particular reference to the Lansjarv area, Northern Sweden, Geolog. Foren. Stock. Forhandlingar, 112 (4), 333-354.

Meghraoui, M., R. JAegy, K. LAmmali and F. Albared (1988): Late Holocene earthquake sequences on the El Asnam (Algeria) trust fault, Earth Planet Sci. Lett., 90, 187-203.

Morner, N.A. and P.E. Troften (1993): Palaeoseismotectonics in glaciated cratonal Sweden, Z. Geomorphol. N.E., 94, 107-117.

Mouyaris, N., D. PAPAstamatiou and C. Vita-Finzi (1992): The Helice fault, Terra Nova, 4, 124-129.

Nikonov, A.A. (1995): The stratigraphic method in the study of large past earthquakes, Quat. Inter., vol. 25, 47-55.

Pantosti, D., D. Schwartz and G., VAlensise (1993): Paleoseismology along the 1980 surface rupture of the Irpinia fault: implications for earthquake recurrence in the Southern Apennines, Italy, J. Geophys. Res., 98 (B4), 6561-6577.

Papanastassiog, D., H. Maroukian and K. GaKi-PAPANASTASSIOU (1993): Morphotectonic and archaeological observations in the Eastern Argive Plain (Eastern Peloponnese, Greece) and their palaeoseismological implications, Z. Geomorphol., N.E., 94, 95-105.
Papazachos, B. and K. Papazachou (1989): The Earthquakes of Greece (in Greek), (Zete, Thessaloniki), pp. 356.

PAVlidES, S. (1994): First palaeoseismological results from Greece, in ESC XXIV General Assembly, Athens, September 1994, abstract, p. 65.

PAVlidES, S. and A.A. KILIAS (1987): Neotectonic and active faults along the Serbomacedonian zone (SE Chalkidiki, N. Greece), Ann. Tectonicae, 1 (2), 97-104.

PAVlides, S. and N. Soulakellis (1990): Multifractured seismogenic area of Thessaloniki 1978 earthquake (N. Greece), in Proceeding IESCA-90 (Savascin and Eronat; Eds.), vol. 2, 64-74.

Pavlides, S., R. Caputo, N. Zouros, D. Mountrakis and M. BocCALETTI (1992): Palaeoseismological history of the Souli Active strike-slip fault (Epirus, NW Greece) abstract, Neotectonics, Quat. Res. Ass. p. 56.

Pavlides, S.B., N.C. Zouros, A.A. Chatzipetros, D.S. Kostopoulos and D.M. Mountrakis (1995): The 13 May 1995 Western Macedonia, Greece (Kozani-Grevena) earthquake; preliminary results, Terra Nova, 7, 544-549.

Prentice, C.S., P.D. Schwartz and R.S. Yeats (1994): Proceedings of the Workshop on Paleoseismology, Marshall, California, 18-22 September 1994, Open-file Report 94-568.

RINGROSE, P.S. (1989): Recent fault movement and palaeoseismicity in Western Scotland, Tectonophysics, 163, 305-314.

SCHWARTZ, P.D. and K.J. COPPERSMITH (1984): Fault behavior and characteristic earthquakes: examples from the Wasatch and San Andreas Fault, J. Geophys. Res., 89, 5681-5698.

SIEH, E.K. (1981): A review of geological evidence for recurrence times of large earthquakes, "Earthquake Prediction», Maurice Ewing Series 4, Am. Geophys Un. 181-207.

StiRos, S. (1988): Archaeology - A tool to study active tectonics. The Aegean as a case study, EOS, Trans. Am. Geophys. Un., 69, 1636-1639.

Stiros, C.S. and A.P. PIRAZzoli (1995): Palaeoseismic studies in Greece: a Review, Quat. Int., 25, 57-63.

VITTORI, E., S.S. LABINI and L. SERVA (1991): Palaeoseismology: review of the state-of-the-art, Tectonophysics, 193, 9-32.

Voidomatis, P.S., S.B. Pavlides and G.A. PaPAdopouLOS (1990): Active deformation and seismic potential in the Serbomacedonia zone, Northern Greece, Tectonophysics, 179, 1-9.

WALLACE, R.E. (1981): Active faults, palaeoseismology, and earthquake hazards in the Western United States, in Earthquake Prediction: an International Review, edited by D.S. SimPSON and P.G. RichardS, Am. Geophys. Un., 209-216.

WALLACE, R. (1987): A perspective of paleoseismology, in «Directions in Paleoseismology» edited by A.J. CRONE and E.M. OMDAHL, USGS Denver, 7-16.

YeAts, R.S. and P.D. SCHWARTZ (1990): Paleoseismicity: extending the record of earthquakes into prehistoric time, Episodes, 13 (1), 9-12.

Zouros, N., S. PAvlides and A. Chatzipetros (1994): Recent movement on the Larissa plain neotectonic faults (Thessaly, C. Greece), Water level fluctuation or tectonic creep? in ESC XXIV General assembly, Athens, September 1994, abstract, p. 67. 